\section{Vol. 65, No. 26}

In the report, "Notes from The Field: Ebola Virus Disease Cluster - Northern Sierra Leone, January 2016," the following two persons should have been included as members of The Interagency Investigation Team: "Kerry Souza, ScD, CDC; Raoul E. Guetiya W, MS, Department of Public Health, University of Makeni, Makeni, Sierra Leone.”

\section{Vol. 65, No. 34}

In the report, "Notes from the Field: Cluster of Lymphogranuloma Venereum Cases Among Men Who Have Sex with Men - Michigan, August 2015-April 2016," on page 920, the first sentence of the third paragraph should have read, "During August 12, 2015-April 30, 2016, MDHHS received 38 reports of LGV all among MSM who were HIV-infected."

\section{Vol. 65, No. 33}

In the report, "Increases in Fentanyl-Related Overdose Deaths - Florida and Ohio, 2013-2015," on page 845, in "FIGURE. Number of fentanyl-related law enforcement submissions* and overdose deaths, and rate of fentanyl prescriptions - Florida and Ohio, January 2013-June 2015," in the Florida line chart, the second and third labels in the legend should be reversed. The second label should read "Fentanylrelated overdose deaths," and the third label should read "Fentanyl-related law enforcement submissions."

On page 846, in "TABLE 1. Demographic characteristics and toxicology findings for fentanyl-related overdose decedents - Florida, 2010-2012, 2013-2014, and January-June, 2015," there were four errors. In the first row, "Total," under 2010-2012, the mean annual rate should read 0.8; under 2013-2014, the mean annual rate should read 1.8; and under \% change from 2010-2012 to 2013-2014, the value should read 121.9*. In the "Cocaine or Heroin" row, the \% change from 2010-2012 to 2013-2014 should read 138.8*. 